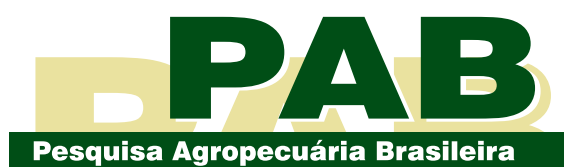

ISSN 1678-3921

Journal homepage: www.embrapa.br/pab

For manuscript submission and journal contents, access: www.scielo.br/pab

\section{Mineralization of pig slurry compost treated with retorted oil shale and dicyandiamide in two contrasting soils}

\begin{abstract}
The objective of this work was to evaluate carbon and nitrogen mineralization in the soil after the application of composts produced in an automated composting plant, using pig slurry (PS) with and without the addition of retorted oil shale (ROS) and dicyandiamide (DCD) during composting. Laboratory studies were carried out for 180 days on two soils with contrasting characteristics: sandy-loam Typic Paludalf and clay Rhodic Hapludox, which were managed for more than 10 years under a no-tillage system. The composts were thoroughly mixed with the soils. The mineralization of the $\mathrm{C}$ and $\mathrm{N}$ from the compost was evaluated by measuring continuously $\mathrm{CO}_{2}$ emissions and periodically mineral $\mathrm{N}\left(\mathrm{NH}_{4}{ }^{+}+\mathrm{NO}_{3}{ }^{-}\right)$content in the soils, respectively. The mineralization of the $\mathrm{C}$ from the compost without ROS and DCD was higher in the sandy-loam soil (20.5\%) than in the clay soil (13.9\%). Similarly, $19.4 \%$ of the total $\mathrm{N}$ from the compost was mineralized in the sandy-loam soil and $10.9 \%$ in the clay soil. The presence of ROS in the compost reduced $\mathrm{C}$ mineralization by $54 \%$, compared with the treatment without additives, in the sandy-loam soil and caused net $\mathrm{N}$ immobilization in both soils during incubation. The addition of DCD during PS composting did not affect the mineralization of the $\mathrm{C}$ and $\mathrm{N}$ from the compost in both soils. The addition of ROS during the composting of PS favors the retention of the $\mathrm{C}$ from the compost in the soil, especially in the sandy-loam one, but results in a net $\mathrm{N}$ immobilization.
\end{abstract}

Index terms: automated composting, carbon dioxide, decomposition, soil texture.

\section{Mineralização de compostos de dejetos líquidos de suínos tratados com xisto retortado e dicianodiamida em dois solos contrastantes}

Resumo - O objetivo deste trabalho foi avaliar a mineralização de carbono e nitrogênio no solo após a aplicação de compostos produzidos numa planta de compostagem automatizada, tendo-se utilizado dejetos líquidos de suínos (DLS), com e sem a adição de xisto retortado (XR) e dicianodiamida (DCD) durante a compostagem. Estudos laboratoriais foram conduzidos durante 180 dias, em dois solos com características contrastantes: Argissolo francoarenoso e Latossolo argiloso, que foram manejados por mais de 10 anos em sistema plantio direto. Os compostos foram completamente misturados com os solos. A mineralização do $\mathrm{C}$ e do $\mathrm{N}$ do composto foi avaliada pela medição contínua do $\mathrm{CO}_{2}$ emitido e periódica do conteúdo de $\mathrm{N}$ mineral $\left(\mathrm{NH}_{4}{ }^{+}+\mathrm{NO}_{3}{ }^{-}\right)$dos solos, respectivamente. A mineralização do $\mathrm{C}$ do composto sem a adição de XR e DCD foi maior no solo franco-arenoso (20.5\%) do 
que no argiloso (13.9\%). Similarmente, $19.4 \%$ do $\mathrm{N}$ total do composto foi mineralizado no solo franco-arenoso e $10.9 \%$ no solo argiloso. A presença do XR no composto reduziu a mineralização do $\mathrm{C}$ em $54 \%$, comparado ao tratamento sem aditivos, no solo franco-arenoso e causou imobilização líquida de $\mathrm{N}$ em ambos os solos durante a incubação. A adição de DCD durante a compostagem dos DLS não afetou a mineralização do $\mathrm{C}$ e do $\mathrm{N}$ do composto em ambos os solos. A adição de XR durante a compostagem dos DLS favorece a retenção do $\mathrm{C}$ do composto no solo, principalmente no franco-arenoso, porém resulta em imobilização líquida de $\mathrm{N}$.

Termos para indexação: compostagem automatizada, dióxido de carbono, decomposição, textura do solo.

\section{Introduction}

The increasing world demand for animal protein has promoted the intensification of pig production in Brazil, which has brought about several negative consequences, both from an agronomic and environmental perspective (Aita et al., 2014). The use of high amounts of water for cleaning animal production facilities generates a large volume of pig slurry (PS), which cannot be transported to distant areas (Oliveira \& Higarashi, 2006). With the frequent and repeated application of PS in the same areas, there is an excess accumulation of macronutrients, especially of phosphorus (Boitt et al., 2018), as well as of micronutrients, such as copper and zinc (De Conti et al., 2016). Furthermore, due to the predominance of the no-tillage system in the Southern region of the country, the manure is to be applied only to soil surface without further incorporation (Aita el al., 2014), a method that favors ammonia $\left(\mathrm{NH}_{3}\right)$ volatilization and the production of bad odors (Webb et al., 2010).

Tomitigate the problemsarising from PS management and use in the no-tillage system, the automated composting system was introduced in the last decade in Brazil. Unlike the traditional composting process, it involves weekly or biweekly slurry additions to the compost piles, with simultaneous turning (Oliveira \& Higarashi, 2006). This process is done mechanically and allows the conversion of PS into a solid matrix (compost), which can be easily transported and used as fertilizer in areas where PS application is not viable. Moreover, composting promotes the biostabilization of organic carbon and the elimination of pathogenic microorganisms in manure, transforming it into a more stable and sanitized product (Bernal et al., 2017). However, there is still a need to improve some potentially negative aspects of composting such as $\mathrm{NH}_{3}$ and nitrous oxide $\left(\mathrm{N}_{2} \mathrm{O}\right)$ emissions.

A number of strategies have been studied to reduce nitrogen losses during composting of animal manure. The main ones involve the use of slurry additives to reduce losses by $\mathrm{NH}_{3}$ volatilization, such as acidification (Doneda, 2014) and the addition of zeolites (Bautista et al., 2011; Giacomini et al., 2014) and biochar (Chen et al., 2017). The application of dicyandiamide (DCD) has been tested in reducing $\mathrm{N}_{2} \mathrm{O}$ emissions during PS composting (Luo et al., 2013). In Brazil, retorted oil shale (ROS), also known as an agromineral, is an abundant solid residue of the thermal transformation of oil shale that has also been used as an additive to reduce $\mathrm{NH}_{3}$ volatilization during PS composting due to its low $\mathrm{pH}$, porous lamellar structure, and surface functional groups (Pimentel et al., 2006), which promote the retention of $\mathrm{N}$ in manure. In the few studies conducted to date, ROS has promoted $\mathrm{C}$ retention in agricultural soils, protecting them from microbial attacks (Doumer et al., 2011; Leão et al., 2014), and did not increase potentially the levels of toxic elements or affect the contents of macronutrients in the soil (Martinazzo et al., 2020).

While the effect of slurry additives on $\mathrm{C}$ and $\mathrm{N}$ losses during manure composting has been investigated (Giacomini, 2017), less attention has been given to the dynamics of these two elements after the application of the compost to the soil. The presence of additives may interfere with the mineralization of the $\mathrm{C}$ and $\mathrm{N}$ from the compost in the soil, because the characteristics of the compost influence soil microbial activity (Pezzolla et al., 2013). Soil characteristics, especially texture, also affect the decomposition of organic composts. The mineralization of $\mathrm{C}$ from an organic compost, for example, is generally lower in fine-textured than in coarse-textured soils (Bustamante et al., 2010).

Therefore, it is necessary to know the amount of $\mathrm{N}$ from the organic composts that is mineralized and the mineralization dynamics in the soil, since the synchronicity of $\mathrm{N}$ supply with crop demand is important both from an agronomic and an environmental perspective (Bernal et al., 2017). While excess $\mathrm{N}$ can lead to plant bedding, air contamination with $\mathrm{NH}_{3}$ and $\mathrm{N}$ oxides, water contamination with 
nitrate $\left(\mathrm{NO}_{3}{ }^{-}\right)$, and $\mathrm{N}$ deficiency negatively affect crop yields (Ghaly \& Ramakrishnan, 2015).

These results show the importance of understanding the dynamics of the soil mineralization of the $\mathrm{C}$ and $\mathrm{N}$ from composts obtained by the automated composting of PS, a recent process that differs from the traditional one.

The objective of this work was to evaluate carbon and nitrogen mineralization in the soil after the application of composts produced in an automated composting plant, using pig slurry (PS) with and without the addition of retorted oil shale (ROS) and dicyandiamide (DCD) during composting.

\section{Materials and Methods}

Two soils contrasting in texture were used: a clay and a sandy-loam soil. Both soils were collected from the surface horizon $(0-10 \mathrm{~cm}$ depth) of two experimental areas that were managed for more than 10 years under a no-tillage system in the state of Rio Grande do Sul, Southern Brazil. The clay soil, classified as a Latossolo Vermelho Eutrófico típico (Santos et al., 2013), i.e., a Rhodic Hapludox (Soil Survey Staff, 2014), was collected in the experimental area of Fundação Centro de Experimentação e Pesquisa/ Cooperativa Central Gaúcha Ltda., in the municipality of Cruz Alta, in the state of Rio Grande do Sul, Brazil $\left(28^{\circ} 33^{\prime} \mathrm{S}, 53^{\circ} 40^{\prime} \mathrm{W}\right)$. The sandy-loam soil, classified as a Argissolo Vermelho Distrófico arênico (Santos et al., 2013), i.e., a Typic Paludalf (Soil Survey Staff, 2014), was collected in the experimental area of the Soils Department of Universidade Federal de Santa Maria, in the municipality of Santa Maria, also in the state of Rio Grande do Sul $\left(29^{\circ} 42^{\prime} \mathrm{S}, 53^{\circ} 42^{\prime} \mathrm{W}\right)$. The Rhodic Hapludox had the following characteristics: $\mathrm{pH}_{(\mathrm{H} 2 \mathrm{O})}$
$5.1,2.4 \%$ total $\mathrm{C}, 0.22 \%$ total $\mathrm{N}, 8.0 \mathrm{mg} \mathrm{kg}^{-1} \mathrm{NH}_{4}{ }^{+}-\mathrm{N}$, $19.9 \mathrm{mg} \mathrm{kg}^{-1} \mathrm{NO}_{3}^{-}-\mathrm{N}$, cation exchange capacity (CEC) of $13.8 \mathrm{cmol}_{\mathrm{c}} \mathrm{dm}^{-3}, 509 \mathrm{~g} \mathrm{~kg}^{-1}$ clay, $215 \mathrm{~g} \mathrm{~kg}^{-1}$ silt, and $276 \mathrm{~g} \mathrm{~kg}^{-1}$ sand. The Typic Paludalf had the following characteristics: $\mathrm{pH}_{(\mathrm{H} 2 \mathrm{O})} 4.7,0.8 \%$ total $\mathrm{C}, 0.08 \%$ total $\mathrm{N}, 9.6 \mathrm{mg} \mathrm{kg}^{-1} \mathrm{NH}_{4}^{+}-\mathrm{N}, 5.8 \mathrm{mg} \mathrm{kg}^{-1} \mathrm{NO}_{3}^{-}-\mathrm{N}, \mathrm{CEC}$ of $7.6 \mathrm{cmol}_{\mathrm{c}} \mathrm{dm}^{-3}, 107 \mathrm{~g} \mathrm{~kg}^{-1}$ clay, $296 \mathrm{~g} \mathrm{~kg}^{-1}$ silt, and 598 $\mathrm{g} \mathrm{kg}^{-1}$ sand. The soils were gently crumbled and sieved at $4 \mathrm{~mm}$, and visible organic residues were removed by hand.

The following composts were applied to the soils: pig slurry (PS) compost, without additives during composting; PS compost + retorted oil shale (ROS), produced with the addition of ROS to PS during composting; and PS compost + ROS + dicyandiamide (DCD), produced with the addition of ROS and DCD to PS during composting. The pig slurry compost was made by mixing $70 \%$ sawdust and $30 \%$ wood shavings with PS in an automated composting platform. The total composting time was 245 days. ROS and DCD were added to the composting piles to reduce emissions of $\mathrm{NH}_{3}, \mathrm{CH}_{4}$, and $\mathrm{N}_{2} \mathrm{O}$ (Giacomini, 2017). The ROS used during composting had a particle size of 0.2 to 1.0 $\mathrm{mm}$, and its main chemical characteristics were: $52 \%$ $\mathrm{SiO}_{2}, 11.5 \% \mathrm{Al}_{2} \mathrm{O}_{3}, 7.5 \% \mathrm{Fe}_{2} \mathrm{O}_{3}, 2.5 \% \mathrm{~K}_{2} \mathrm{O}, 2.2 \% \mathrm{CaO}$, and $1.7 \% \mathrm{MgO}$. The main minerals that composed the ROS were: quartz, plagioclase, pyrite, and argillaceous minerals (e.g., illite, smectite, chlorite, and kaolinite). More details of the composting process are described in Giacomini (2017).

The total organic $\mathrm{C}$ and $\mathrm{N}$ from the composts were determined by dry combustion in the FlashEA 1112 elemental analyzer (Thermo Electron Corporation, Milan, Italy), while inorganic $\mathrm{N}$ content was obtained according to Tedesco et al. (1995). The main characteristics of the composts are shown in Table 1.

Table 1. Characteristics and quantities of the composts applied to clay and sandy-loam soils on a dry weight basis.

\begin{tabular}{|c|c|c|c|c|c|c|c|}
\hline \multirow[t]{2}{*}{ Organic compost ${ }^{(1)}$} & $\mathrm{DM}^{(2)}$ & Total C & Total N & $\mathrm{NH}_{4}{ }^{+}-\mathrm{N}$ & $\mathrm{NO}_{3}-\mathrm{N}$ & $\mathrm{C} / \mathrm{N}^{(3)}$ & $\mathrm{pH}$ \\
\hline & \multicolumn{7}{|c|}{ 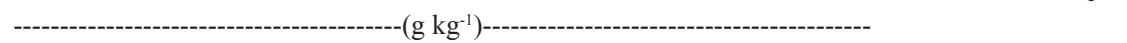 } \\
\hline PS compost & 335.0 & 378.4 & 26.9 & 0.41 & 0.022 & 14.0 & 6.6 \\
\hline PS compost + ROS & 525.0 & 257.9 & 11.0 & 0.15 & 0.002 & 23.0 & 6.4 \\
\hline PS compost + ROS + DCD & 522.0 & 231.9 & 12.0 & 0.17 & 0.001 & 19.0 & 7.8 \\
\hline Quantities applied & \multicolumn{7}{|c|}{--------------(g per kg of soil)-------------- } \\
\hline PS compost & 37.2 & 14.1 & 1.0 & 15.2 & 0.8 & & \\
\hline PS compost + ROS & 90.9 & 23.5 & 1.0 & 14.0 & 0.2 & & \\
\hline PS compost + ROS + DCD & 83.3 & 19.3 & 1.0 & 14.2 & 0.1 & & \\
\hline
\end{tabular}

(1)PS, pig slurry; ROS, retorted oil shale; and DCD, dicyandiamide. ${ }^{(2)} \mathrm{DM}$, dry matter. ${ }^{(3)} \mathrm{Carbon} /$ nitrogen ratio. 
Laboratory incubations were carried out in the dark, at a constant temperature of $25^{\circ} \mathrm{C}$, at a constant soil water content of $80 \%$ field capacity, and under aerobic conditions for 180 days. The treatments consisted of the combination of the two soils (sandy-loam and clay) and of the three types of composts (PS compost, PS compost + ROS, and PS compost + ROS + DCD). For each soil, an unamended soil was used as the control, resulting in eight treatments. The treatments were arranged in a completely randomized design, with four replicates for each treatment. For each replicate, samples of 74 and $83 \mathrm{~g}$ moist sandy-loam and clay soils, respectively, were used, being equivalent to 65 g dry soil.

In each experimental unit, the soil mass was placed in a $110 \mathrm{~mL}$ cylindrical acrylic pot $(5.0 \mathrm{~cm}$ in diameter and $5.0 \mathrm{~cm}$ in height) and gently compressed to a height of $5.0 \mathrm{~cm}$. The composts were thoroughly mixed with the soil at a rate of: $37.2 \mathrm{~g}$ dry matter (DM) of the PS compost per kilogram of soil, $90.2 \mathrm{~g}$ DM of the PS compost + ROS per kilogram of soil, and $83.3 \mathrm{~g} \mathrm{DM}$ of the PS compost + ROS + DCD per kilogram of soil, which was equivalent to the addition of $1.0 \mathrm{~g} \mathrm{~N}$ per kilogram of dry soil $\left(550 \mathrm{~kg} \mathrm{ha}^{-1} \mathrm{~N}\right)$. The rates of the composts were established assuming a mineralization index of $10 \%$ total N (Cantú, 2014). As the rate of the composts was based on total $\mathrm{N}$ content, the addition of $\mathrm{C}$ differed between the composts (Table 1). The water content was adjusted by adding distilled water to correct for weight loss due to soil moisture evaporation. The pots were aerated periodically to avoid $\mathrm{O}_{2}$ deficiency.

The mineralization of the $\mathrm{C}$ from the compost was assessed by quantifying $\mathrm{CO}_{2}$ emission, according to Stotzky (1965). Four acrylic pots of each treatment were incubated separately, each in a $1,000 \mathrm{~mL}$ glass jar, where the evolved $\mathrm{CO}_{2}$ was trapped with $10 \mathrm{~mL}$ of $1.0 \mathrm{~mol} \mathrm{~L}^{-1} \mathrm{NaOH}$ in a beaker placed inside each glass jar. Four empty jars were used as blanks. The beakers containing $\mathrm{NaOH}$ were changed at each sampling time, i.e., at 1, 3, 7, 12, 20, 29, 44, 59, 73, 90, 104, $119,134,147$, and 180 days. The amount of evolved $\mathrm{CO}_{2}$ was quantified by titrating the unreacted $\mathrm{NaOH}$ with $1.0 \mathrm{~mol} \mathrm{~L}^{-1} \mathrm{HCl}$ after the precipitation of the carbonates formed with $2.0 \mathrm{~mol} \mathrm{~L}^{-1} \mathrm{BaCl}_{2}$. Assuming that soil respiration changed linearly between the nearest sampling dates, the emission of $\mathrm{CO}_{2}$ (expressed in $\mathrm{mg} \mathrm{CO}_{2}-\mathrm{C}$ per kilogram of soil) was calculated as the product of the mean $\mathrm{CO}_{2}$ efflux and the time between successive respiration measurements. The cumulative $\mathrm{CO}_{2}-\mathrm{C}$ was calculated based on the amount of evolved $\mathrm{CO}_{2}$ in each treatment during incubation. The percentage of applied organic $\mathrm{C}$ released as $\mathrm{CO}_{2}-\mathrm{C}$ was determined by subtracting the amounts of $\mathrm{CO}_{2}-\mathrm{C}$ emitted from the unamended control soil from those emitted from each amended soil receiving each compost type, then divided by the quantity of $\mathrm{C}$ added by each compost.

In the series set up to assess $\mathrm{N}$ dynamics, the acrylic pots were incubated in 2,000 mL glass jars, with four replicates of each treatment per jar. All jars were opened periodically, aerated for a few minutes to renew the atmosphere inside them, and their soil water content was checked by weighing and, when necessary, adjusted with a micropipette. Soil mineral $\mathrm{N}\left(\mathrm{NH}_{4}{ }^{+}\right.$and $\left.\mathrm{NO}_{2}{ }^{-}+\mathrm{NO}_{3}{ }^{-}\right)$was measured in all treatments at $0,5,10,20,40,80$, and 180 days of incubation. Mineral $\mathrm{N}$ was extracted from fresh soil samples with $1.0 \mathrm{~mol} \mathrm{~L}^{-1} \mathrm{KCl}$, shaken for $30 \mathrm{~min}$, with a soil:solution ratio of 1:4. The soil $\mathrm{KCl}$ suspension was settled for $30 \mathrm{~min}$, the supernatant was filtered using a Whatman grade 42 filter paper (Sigma-Aldrich Corp., St. Louis, MO, USA), and then frozen until analysis by steam distillation (Tedesco et al., 1995). The amount of mineralized N (mg N per kilogram of dry soil) was calculated taking into account the amount of inorganic $\mathrm{N}$ in the soil of the treatments with the composts at the beginning $\left(\mathrm{TN}_{1}\right)$ and at the end $\left(\mathrm{TN}_{2}\right)$ of each evaluation period, as well as the amount of inorganic $\mathrm{N}$ in the soil in the control treatment at the beginning $\left(\mathrm{CN}_{1}\right)$ and at the end $\left(\mathrm{CN}_{2}\right)$ of each evaluation period, according to the following equation: $\mathrm{N} \min =\left(\mathrm{TN}_{2}-\mathrm{TN}_{1}\right)-\left(\mathrm{CN}_{2}-\mathrm{CN}_{1}\right)$. Positive values indicate net $\mathrm{N}$ mineralization, while negative ones, net $\mathrm{N}$ immobilization.

The cumulative emission of $\mathrm{CO}_{2}$, inorganic $\mathrm{N}$ content in the soil, and amount of $\mathrm{N}$ mineralized at the end of the incubation period were subjected to the analysis of variance, using the Sisvar, version 5.6, software (Ferreira, 2011). The analysis of these variables considered the type of soil and compost and the interaction between them. Means were compared between soils by Tukey's test, at 5\% probability, and within each soil by orthogonal contrasts, comparing the influence of the compost (composts vs. control), the influence of the additives (compost without additives vs. compost with additives), and the influence of DCD (ROS compost vs. ROS + DCD compost); differences were considered significant at $5 \%$ probability. 


\section{Results and Discussion}

The emission of $\mathrm{CO}_{2}$ was lower in the control treatment during the incubation period, with mean values of 6.5 and $3.5 \mathrm{mg} \mathrm{C}$ per kilogram of soil per day in the clay and sandy-loam soils, respectively (Figure $1 \mathrm{~A}$ and $\mathrm{B}$ ). The addition of the three tested composts in the soils increased the mean $\mathrm{CO}_{2}$ flux 3.3 times in the clay soil and 5.2 times in the sandyloam one. Overall, the highest $\mathrm{CO}_{2}$ emission rates occurred in the first days of incubation, which is due to the presence of labile $\mathrm{C}$ in the composts (Guerrero et al., 2007; Grave et al., 2015). Despite the partial biostabilization of organic material during composting, fractions of labile organic $\mathrm{C}$ can still remain in the final compost (Said-Pullicino et al., 2007; Bustamante et al., 2010). These fractions are rapidly metabolized by soil microorganisms, resulting in the rapid release of $\mathrm{CO}_{2}$ through respiration (Pezzolla et al., 2013).

From 29 to 59 days of incubation, $\mathrm{CO}_{2}$ fluxes increased in the three treatments with compost in the clay soil (Figure 1 A). However, this increase was less significant in the sandy-loam soil, occurring mainly in the PS compost treatment (Figure 1 B). The increased release of $\mathrm{CO}_{2}$ after the initial phase is indicative of the decomposition of a more recalcitrant organic fraction of the composts by a distinct microbial population (Cayuela et al., 2009). Soils with a higher organic matter content (such as the clay soil) may present microorganisms adapted to decompose materials
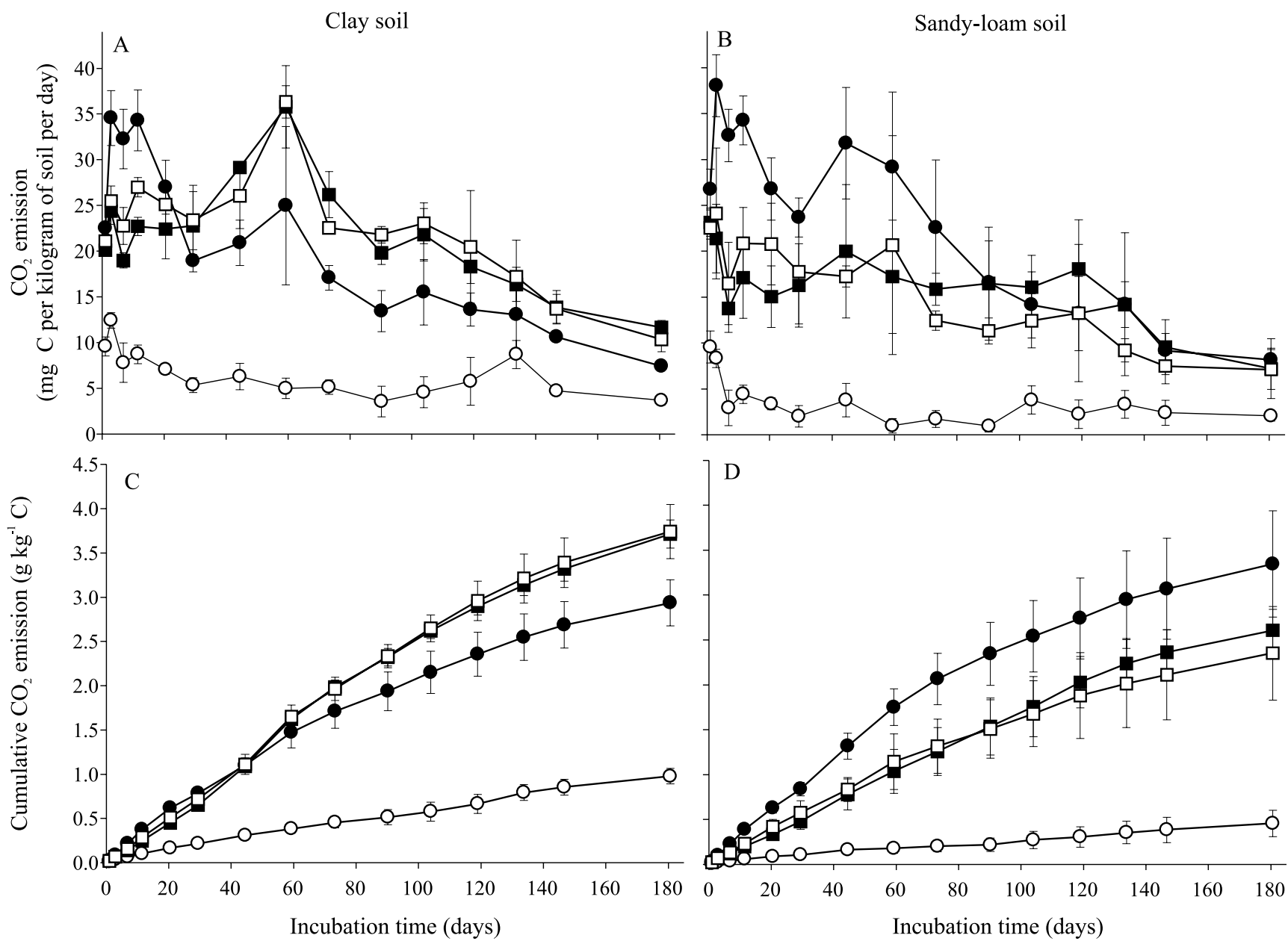

$\mathrm{D}$

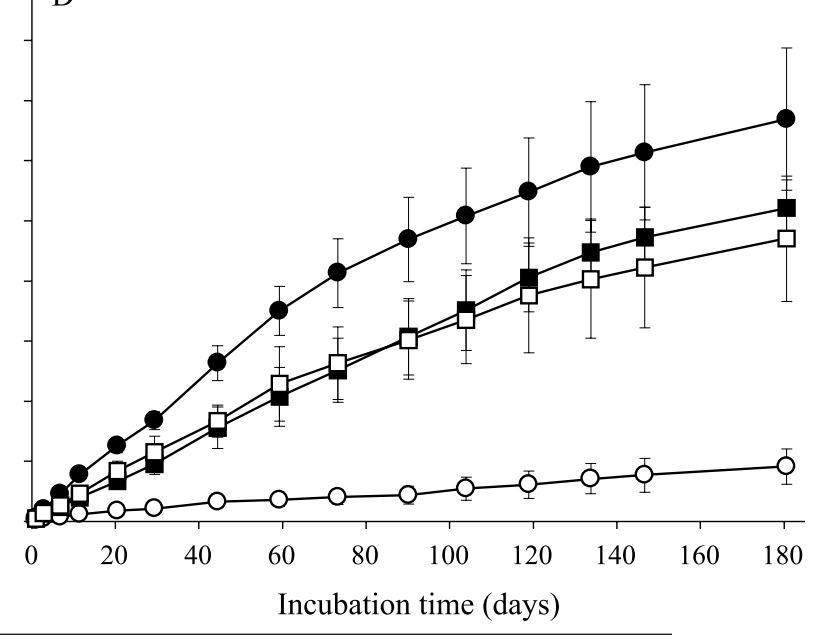

- - Control $\longrightarrow$ PS compost + ROS

- PS compost

$\square-$ PS compost + ROS + DCD

Figure 1. $\mathrm{CO}_{2}$ emission (A and $\mathrm{B}$ ) and cumulative $\mathrm{CO}_{2}$ emission $(\mathrm{C}$ and $\mathrm{D})$ after the application of pig slurry (PS) composts with and without additives to clay and sandy-loam soils. The vertical bars indicate standard deviation $(\mathrm{n}=4)$. ROS, retorted oil shale; and DCD, dicyandiamide. 
that are difficult to degrade, besides having a greater microbial substrate, which increases the chance of the microorganisms to be physically in contact with recalcitrant organic particles (Ameloot et al., 2015).

After 60 days of incubation, the rate of the mineralization of the $\mathrm{C}$ from the compost slowly decreased until the end of the experiment, confirming the results of other studies (Bustamante et al., 2010; Pezzolla et al., 2013). This behavior indicates that the microbial activity in both evaluated soils was gradually limited by a reduced substrate availability for biosynthesis and energy production.

There was a significant interaction between the types of soil and composts for the cumulative emission of $\mathrm{CO}_{2}$ and the amount of mineralized $\mathrm{C}$ (Table 2). The cumulative emission of $\mathrm{CO}_{2}$ did not differ between soils treated with the PS compost. However, there was a greater mineralization of the $\mathrm{C}$ of this compost in the sandy-loam soil, in comparison with the clay soil ( 20.5 vs. $13.9 \%$ of the added C). This is most likely related to soil texture since the Typic Paludalf has a low clay content, which provided little protection against microbial decomposition (Bustamante et al., 2010), whereas the Rhodic Hapludox has a clay content with a greater capacity to stabilize organic $\mathrm{C}$ on clay surfaces through sorption or physical protection within stable aggregates (Bustamante et al., 2010), reducing the decomposition rates of the PS compost. This explanation is also supported by Duong et al. (2012), who found that soil respiration was significantly higher in the soil with $13 \%$ clay than in the one with $46 \%$, both amended with two types of composts.

The composts obtained with the addition of ROS and ROS + DCD to PS during composting showed distinct behaviors regarding $\mathrm{C}$ mineralization in both soils. In the clay soil, the average cumulative $\mathrm{CO}_{2}$ emission of these two composts was $27 \%$ higher than that of the compost without additives (PS compost), whereas, in the sandy-loam soil, both treatments showed a $\mathrm{CO}_{2}$ emission $26 \%$ lower than that of the PS compost (Figure $1 \mathrm{C}$ and D; Table 2). Although the cumulative $\mathrm{CO}_{2}$ emission in the clay soil was higher after the application of the composts with additives, the proportion of $\mathrm{C}$ that was mineralized did not differ among the composts, with an average value of $13.3 \%$ (Table 2). However, in the sandy-loam soil, the average cumulative $\mathrm{CO}_{2}$ emission of the composts with additives was lower than that of the compost without additives (2.48 vs. $3.35 \mathrm{~g} \mathrm{CO}_{2}$ - $\mathrm{C}$ per kilogram of soil). Likewise, the average mineralization of the $\mathrm{C}$ added to the sandy-loam soil was lower in the two treatments with additives ( $9.5 \%)$, compared with the compost without them $(20.5 \%)$. These results suggest that, besides soil texture, the addition of ROS to PS during composting affected the mineralization of the $\mathrm{C}$ from the compost, probably because the agromineral plays a similar role to clay due to its characteristics, which may help in the physical and chemical protection of organic composts (Doumer et al., 2011; Leão et al., 2014). This is possible because ROS is derived from rocks composed mainly of clay minerals, quartz, feldspars, micas, as well as pyrite and carbonates (Pimentel et al., 2006), which remain unchanged after pyrolysis (Ribas, 2012). Therefore, the effect of ROS on reducing $\mathrm{C}$ mineralization was observed only in the sandy-loam soil, which has a lower clay content of $107 \mathrm{~g} \mathrm{~kg}^{-1}$, compared with that of $509 \mathrm{~g} \mathrm{~kg}^{-1}$ of the clay soil. These results indicate that the addition of ROS

Table 2. Cumulative $\mathrm{CO}_{2}$ emissions and percentage of mineralized carbon in clay and sandy-loam soils treated with pig slurry (PS) composts with and without additives ${ }^{(1)}$.

\begin{tabular}{|c|c|c|c|c|}
\hline \multirow[t]{2}{*}{ Treatment } & \multicolumn{2}{|c|}{ Cumulative $\mathrm{CO}_{2}$ emission } & \multicolumn{2}{|c|}{ Total C mineralized } \\
\hline & Clay & Sandy loam & Clay & Sandy loam \\
\hline & \multicolumn{2}{|c|}{-----------( $\left(\mathrm{g} \mathrm{CO}_{2}\right.$-C per kg)----------- } & \multicolumn{2}{|c|}{ 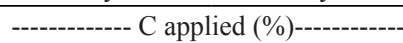 } \\
\hline Control (A) & $0.98 \mathrm{a}$ & $0.45 b$ & - & - \\
\hline PS compost (B) & $2.94 \mathrm{a}$ & $3.35 \mathrm{a}$ & $13.9 \mathrm{~b}$ & $20.5 \mathrm{a}$ \\
\hline PS compost + ROS $(C)$ & $3.71 \mathrm{a}$ & $2.61 \mathrm{~b}$ & $11.7 \mathrm{a}$ & $9.2 \mathrm{a}$ \\
\hline PS compost + ROS + DCD (D) & $3.74 \mathrm{a}$ & $2.35 \mathrm{~b}$ & $14.3 \mathrm{a}$ & $9.8 \mathrm{~b}$ \\
\hline \multicolumn{5}{|l|}{ Orthogonal contrasts } \\
\hline A vs. B, C, D & $-2.48^{* *}$ & $-2.32 * *$ & - & - \\
\hline B vs. C, D & $-0.79 * *$ & $0.87 * *$ & $0.9^{\mathrm{ns}}$ & $12.2 * *$ \\
\hline C vs. D & $-0.02^{\mathrm{ns}}$ & $0.25^{\mathrm{ns}}$ & $-2.6^{\mathrm{ns}}$ & $-2.9^{\text {ns }}$ \\
\hline
\end{tabular}

(1)Means followed by equal letters, within lines, do not differ significantly by Tukey's test, at $5 \%$ probability. ROS, retorted oil shale; and DCD, dicyandiamide. ${ }^{* *}$ Orthogonal contrasts significant at $\mathrm{p}<0.01$. ${ }^{\text {ns }}$ Nonsignificant orthogonal contrasts. 
to PS during composting may constitute a strategy to increase the retention of the $\mathrm{C}$ from the compost in sandy-textured soils.

The addition of DCD to PS during composting had no effect on cumulative $\mathrm{CO}_{2}$ emission and on the mineralization of the $\mathrm{C}$ from the compost in both soils (Table 2). The increase in temperature during the thermophilic phase of composting may have contributed to the biodegradation of DCD (Giacomini, 2017), as its half-life decreases with increasing temperatures (McGeough et al., 2016). In the study by Kelliher et al. (2008), the half-life of DCD reduced from 110 to 20 days when the soil temperature rose from 5 to $25^{\circ} \mathrm{C}$. In one of the few researches in which the additive was used in the composting of pig manure, Luo et al.
(2013) found that the effect of DCD on the composting process occurred in less than 8 days; the compost used by Giacomini (2017) remained in the stabilization phase without DCD addition for 95 days. Therefore, the rising temperature most likely contributed to the complete biodegradation of the molecule and to a similar behavior between the PS compost + ROS and PS compost + ROS + DCD treatments regarding the soil mineralization of $\mathrm{C}$.

There was a significant interaction between soils and composts for the content of mineral $\mathrm{N}$ in the soil and the amount of mineralized $\mathrm{N}$ from the composts at the end of incubation. The mineral $\mathrm{N}$ content in the control increased during incubation in both soils

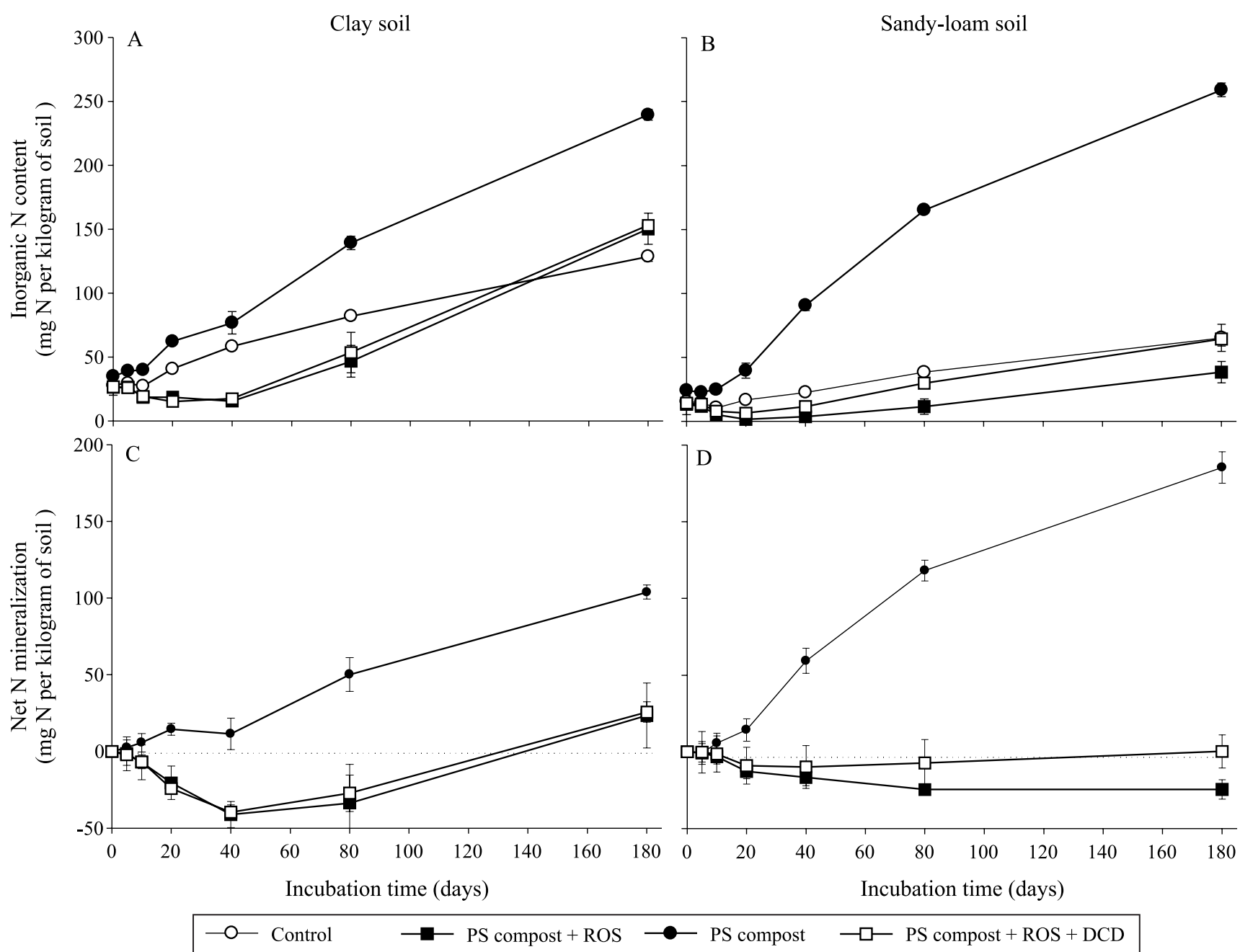

Figure 2. Evolution of inorganic nitrogen content (A and $\mathrm{B}$ ) and net $\mathrm{N}$ mineralization/immobilization (C and D) in clay and sandy-loam soils treated with pig slurry (PS) composts with and without additives. The vertical bars indicate standard deviation $(n=4)$. ROS, retorted oil shale; and DCD, dicyandiamide. 
(Figure $2 \mathrm{~A}$ and $\mathrm{B}$ ), being two times higher in the clay soil than in the sandy-loam one (128.5 vs. 65.2 mg N per kilogram of soil) at the end of incubation. The higher organic matter content in the clay soil, compared with that in the sandy-loam soil (4.1 vs. $1.4 \%$ ), combined with sieving and rewetting of the soil prior to incubation, favored the mineralization of soil organic matter, which promoted a greater accumulation of mineral $\mathrm{N}$ in the clay soil.

The addition of the compost without additives (PS compost) to the soil significantly increased mineral $\mathrm{N}$ content in both soils (Figure $2 \mathrm{~A}$ and $\mathrm{B}$ ), when compared with the control. Moreover, the cumulative net mineralization was higher in the sandy-loam soil than in the clay one (194.0 vs. $110.9 \mathrm{mg} \mathrm{N}$ per kilogram of soil) (Figure $2 \mathrm{C}$ and $\mathrm{D}$ ). These values correspond to a net $\mathrm{N}$ mineralization of 19.4 and $10.9 \%$ with the addition of the PS compost, respectively, in the sandy-loam and clay soils. These results are in agreement with those of other studies that reported a negative correlation between soil clay content and the $\mathrm{N}$ mineralization of plant residues, chicken manure (Khalil et al., 2005), and organic compost (Nendel et al., 2004).

The composts produced with ROS and ROS + DCD during composting promoted net $\mathrm{N}$ immobilization during most of the incubation period in both soils (Figure $2 \mathrm{C}$ and $\mathrm{D}$ ). The highest values were $-40 \mathrm{mg}$ $\mathrm{N}$ per kilogram of soil in the clay soil and $-24.5 \mathrm{mg} \mathrm{N}$ per kilogram of soil in the sandy-loam soil at 40 and 80 days, respectively. At the end of incubation (180 days), the average reduction in mineral $\mathrm{N}$ content in the treatments with additives was $37 \%$ in the clay soil and $80 \%$ in the sandy-loam one, compared with the compost without additive (PS compost) (Table 3 ). This effect has also been observed in studies with biochar (Nguyen et al., 2017), being attributed to the high $\mathrm{C} / \mathrm{N}$ ratio and $\mathrm{N}$ adsorption by the residue. In the present study, the $\mathrm{C} / \mathrm{N}$ ratio of $\sim 18.6$ of the composts cannot be considered favorable to microbial immobilization (Table 1), since the $\mathrm{N}$ mineralization process predominates in the decomposition of organic residues with a $\mathrm{C} / \mathrm{N}$ ratio below 25 (Paul, 2015). Therefore, the adsorption of inorganic $\mathrm{N}$ by the soil through the active ROS sites present in the composts is most likely the primary mechanism responsible for reducing the amount of soil mineral $\mathrm{N}$ in treatments with ROS.

The dynamics of the mineralization of the $\mathrm{C}$ and $\mathrm{N}$ from the composts in the soil indicate that the addition of ROS to PS during composting is a positive practice in terms of increasing soil $\mathrm{C}$ retention. However, it causes a reduction in $\mathrm{N}$ availability during the decomposition of the composts. Therefore, the addition of composts with additives to the soil may be a recommended practice for crops, such as legumes, that are not demanding regarding the external supply of N. For future studies, molecular methods could be used to try to identify changes in the structure of soil heterotrophic microbial populations caused by the use of ROS.

Table 3. Inorganic nitrogen content and percentage of total mineralized $\mathrm{N}$ in clay and sandy-loam soils treated with pig slurry (PS) composts with and without additives ${ }^{(1)}$.

\begin{tabular}{|c|c|c|c|c|}
\hline \multirow[t]{2}{*}{ Treatment } & \multicolumn{2}{|c|}{$\mathrm{N}$ content } & \multicolumn{2}{|c|}{ Total mineralized $\mathrm{N}$} \\
\hline & Clay & Sandy loam & Clay & Sandy loam \\
\hline & \multicolumn{2}{|c|}{ - } & \multicolumn{2}{|c|}{------ N applied (\%) -------. } \\
\hline Control & $128.5 \mathrm{a}$ & $65.2 \mathrm{~b}$ & - & - \\
\hline PS compost & $239.4 b$ & $259.2 \mathrm{a}$ & $10.9 \mathrm{~b}$ & $19.4 \mathrm{a}$ \\
\hline PS compost + ROS & $150.2 \mathrm{a}$ & $38.4 \mathrm{~b}$ & $2.0 \mathrm{a}$ & $-2.1 b$ \\
\hline PS compost + ROS + DCD & $153.0 \mathrm{a}$ & $64.2 \mathrm{~b}$ & $2.7 \mathrm{a}$ & $0.0 \mathrm{~b}$ \\
\hline \multicolumn{5}{|l|}{ Orthogonal contrasts } \\
\hline A vs. B, C, D & $-52.3^{* *}$ & $-55.4 * *$ & - & - \\
\hline B vs. C, D & $87.8 * *$ & $207.8^{* *}$ & $8.5^{* *}$ & $20.4^{* *}$ \\
\hline C vs. D & $-2.7^{\mathrm{ns}}$ & $-25.8 * *$ & $-0.7 \mathrm{~ns}$ & $-2.1 * *$ \\
\hline
\end{tabular}

${ }^{(1)}$ Means followed by equal letters, within lines, do not differ significantly by Tukey’s test, at 5\% probability. ROS, retorted oil shale; and DCD, dicyandiamide. **Orthogonal contrasts significant at $\mathrm{p}<0.01$. ${ }^{\mathrm{ns}}$ Nonsignificant orthogonal contrasts. 


\section{Conclusions}

1. The mineralization of the carbon and nitrogen from composts is higher in the sandy-loam soil than in the clay one, showing that soil characteristics (especially texture) influence the decomposition of the evaluated composts.

2. The mineralization of the $\mathrm{C}$ from the pig slurry compost with retorted oil shale is lower in the sandyloam soil, compared with the clay one, suggesting that the application of this compost to sandy soils may increase soil $\mathrm{C}$ retention.

3. Net $\mathrm{N}$ immobilization promoted by the presence of retorted oil shale in the pig slurry compost indicates the low potential of the compost as a $\mathrm{N}$ fertilizer.

4. The mineralization of the $\mathrm{C}$ and $\mathrm{N}$ from the pig slurry compost in the soil is not affected by the addition of dicyandiamide during pig slurry composting.

\section{Acknowledgments}

To Embrapa Clima Temperado, to Projeto Xisto Agrícola (SIX) of Petróleo Brasil S/A (Petrobras), to Conselho Nacional de Desenvolvimento Científico e Tecnológico (CNPq), and to Coordenação de Aperfeiçoamento de Pessoal de Nível Superior (Capes, Finance Code 001), for financial support.

\section{References}

AITA, C.; GONZATTO, R.; MIOLA, E.C.C.; SANTOS, D.B. dos; ROCHETTE, P.; ANGERS, D.A.; CHANTIGNY, M.H.; PUJOL, S.B.; GIACOMINI, D.A.; GIACOMINI, S.J. Injection of dicyandiamide-treated pig slurry reduced ammonia volatilization without enhancing soil nitrous oxide emissions from no-till corn in southern Brazil. Journal of Environmental Quality, v.43, p.789-800, 2014. DOI: https://doi.org/10.2134/jeq2013.07.0301.

AMELOOT, N.; SLEUTEL, S.; DAS, K.C.; KANAGARATNAM, J.; DE NEVE, S. Biochar amendment to soils with contrasting organic matter level: effects on $\mathrm{N}$ mineralization and biological soil properties. GCB Bioenergy, v.7, p.135-144, 2015. DOI: https://doi.org/10.1111/gcbb.12119.

BAUTISTA, J.M.; KIM, H.; AHN, D.-H.; ZHANG, R.; OH, Y.$\mathrm{S}$. Changes in physicochemical properties and gaseous emissions of composting swine manure amended with alum and zeolite. Korean Journal of Chemical Engineering, v.28, p.189-194, 2011. DOI: https://doi.org/10.1007/s11814-010-0312-6.

BERNAL, M.P.; SOMMER, S.G.; CHADWICK, D.; QING, C.; GUOXUE, L.; MICHEL JR., F.C. Current approaches and future trends in compost quality criteria for agronomic, environmental, and human health benefits. Advances in Agronomy, v.144, p.143233, 2017. DOI: https://doi.org/10.1016/bs.agron.2017.03.002.
BOITT, G.; SCHMITT, D.E.; GATIBONI, L.C.; WAKELIN, S.A.; BLACK, A.; SACOMORI, W.; CASSOL, P.C.; CONDRON, L.M. Fate of phosphorus applied to soil in pig slurry under cropping in southern Brazil. Geoderma, v.321, p.164-172, 2018. DOI: https://doi.org/10.1016/j.geoderma.2018.02.010.

BUSTAMANTE, M.A.; SAID-PULLICINO, D.; PAREDES, C.; CECILIA, J.A.; MORAL, R. Influences of winery-distillery waste compost stability and soil type on soil carbon dynamics in amended soils. Waste Management, v.30, p.1966-1975, 2010. DOI: https://doi.org/10.1016/j.wasman.2010.03.012.

CANTÚ, R.R. Acidificação de dejetos de suínos em compostagem automatizada: emissões gasosas de nitrogênio e resposta da alface à aplicação do composto no solo. 2014. 90p. Tese (Doutorado) Universidade Federal de Santa Maria, Santa Maria.

CAYUELA, M.L.; SINICCO, T.; MONDINI, C. Mineralization dynamics and biochemical properties during initial decompostion of plant and animal residues in soil. Applied Soil Ecology, v.41, p.118-127, 2009. DOI: https://doi.org/10.1016/j.apsoil.2008.10.001.

CHEN, W.; LIAO, X.; WU, Y.; LIANG, J.B.; MI, J.; HUANG, J.; ZHANG, H.; WU, Y.; QIAO, Z.; LI, X.; WANG, Y. Effects of different types of biochar on methane and ammonia mitigation during layer manure composting. Waste Management, v.61, p.506515, 2017. DOI: https://doi.org/10.1016/j.wasman.2017.01.014.

DE CONTI, L.; CERETTA, C.A.; FERREIRA, P.A.A.; LOURENZI, C.R.; GIROTTO, E.; LORENSINI, F.; TIECHER, T.L.; MARCHEZAN, C.; ANCHIETA, M.G.; BRUNETTO, G. Soil solution concentrations and chemical species of copper and zinc in a soil with a history of pig slurry application and plant cultivation. Agriculture, Ecosystems \& Environment, v.216, p.374-386, 2016. DOI: https://doi.org/10.1016/j.agee.2015.09.040.

DONEDA, A. A acidificação de dejetos líquidos de suínos afeta as emissões de amônia e gases de efeito estufa no processo de compostagem automatizada. 2014. 99p. Tese (Doutorado) Universidade Federal de Santa Maria, Santa Maria.

DOUMER, M.E.; GIACOMINI, S.J.; SILVEIRA, C.A.P.; WEILER, D.A.; BASTOS, L.M.; FREITAS, L.L. de. Atividade microbiana e enzimática em solo após a aplicação de xisto retortado. Pesquisa Agropecuária Brasileira, v.46, p.1538-1546, 2011. DOI: https://doi.org/10.1590/S0100-204X2011001100016.

DUONG, T.T.T.; PENFOLD, C.; MARSCHNER, P. Differential effects of composts on properties of soils with different textures. Biology and Fertility of Soils, v.48, p.699-707, 2012. DOI: https://doi.org/10.1007/s00374-012-0667-4.

FERREIRA, D.F. Sisvar: a computer statistical analysis system. Ciência e Agrotecnologia, v.35, p.1039-1042, 2011. DOI: https://doi.org/10.1590/S1413-70542011000600001.

GHALY, A.E.; RAMAKRISHNAN, V.V. Nitrogen sources and cycling in the ecosystem and its role in air, water and soil pollution: a critical review. Journal of Pollution Effects \& Control, v.3, art.136, 2015. DOI: https://doi.org/10.4172/2375-4397.1000136.

GIACOMINI, D.A. Estratégias para mitigar as emissões de $\mathrm{NH}_{3}, \mathrm{~N}_{2} \mathrm{O}$ e $\mathrm{CH}_{4}$ em compostagem automatizada de dejetos líquidos de suínos. 2017. 81p. Tese (Doutorado) - Universidade Federal de Santa Maria, Santa Maria.

GIACOMINI, D.A.; AITA, C.; PUJOL, S.B.; GIACOMINI, S.J.; DONEDA, A.; CANTÚ, R.R.; DESSBESELL, A.; LÜDTKE, 
R.C.; SILVEIRA, C.A.P. Mitigação das emissões de amônia por zeólitas naturais durante a compostagem de dejetos de suínos. Pesquisa Agropecuária Brasileira, v.49, p.521-530, 2014. DOI: https://doi.org/10.1590/S0100-204X2014000700004.

GRAVE, R.A.; NICOLOSO, R. da S.; CASSOL, P.C.; AITA, C.; CORREAA, J.C.; COSTA, M.D.; FRITZ, D.D. Short-term carbon dioxide emission under contrasting soil disturbance levels and organic amendments. Soil and Tillage Research, v.146, Part B, p.184-192, 2015. DOI: https://doi.org/10.1016/j.still.2014.10.010.

GUERRERO, C.; MORAL, R.; GÓMEZ, I.; ZORNOZA, R.; ARCENEGUI, V. Microbial biomass and activity of an agricultural soil amended with the solid phase of pig slurries. Bioresource Technology, v.98, p.3259-3264, 2007. DOI: https://doi.org/10.1016/j.biortech.2006.07.015.

KELLIHER, F.M.; CLOUGH, T.J.; CLARK, H.; RYS, G.; SEDCOLE, J.R. The temperature dependence of dicyandiamide (DCD) degradation in soils: a data synthesis. Soil Biology and Biochemistry, v.40, p.1878-1882, 2008. DOI: https://doi.org/10.1016/j.soilbio.2008.03.013.

KHALIL, M.I.; HOSSAIN, M.B.; SCHMIDHALTER, U. Carbon and nitrogen mineralization in different upland soils of the subtropics treated with organic materials. Soil Biology and Biochemistry, v.37, p.1507-1518, 2005. DOI: https://doi.org/10.1016/j.soilbio.2005.01.014.

LEÃO, R.E.; GIACOMINI, S.J.; REDIN, M.; SOUZA, E.L.; SILVEIRA, C.A.P. A adição de xisto retortado aumenta a retenção do carbono de resíduos vegetais no solo. Pesquisa Agropecuária Brasileira, v.49, p.818-822, 2014. DOI: https://doi.org/10.1590/ S0100-204X2014001000009.

LUO, Y.; LI, G.; LUO, W.; SCHUCHARDT, F.; JIANG, T.; XU, D. Effect of phosphogypsum and dicyandiamide as additives on $\mathrm{NH}_{3}, \mathrm{~N}_{2} \mathrm{O}$ and $\mathrm{CH}_{4}$ emissions during composting. Journal of Environmental Sciences, v.25, p.1338-1345, 2013. DOI: https://doi.org/10.1016/S1001-0742(12)60126-0.

MARTINAZZO, R.; SILVEIRA, C.A.P.; BAMBERG, A.L.; STUMPF, L.; STOCKER, C.M.; MONTEIRO, A.B.; PEREIRA, I. dos S.; RIBEIRO, P.L.; GIACOMINI, S.J. Incorporation of retorted oil shale in Brazilian agricultural soil: an assessment of impacts after successive applications. Journal of Cleaner Production, v.245, art.118652, 2020. DOI: https://doi.org/10.1016/j. jclepro.2019.118652.

MCGEOUGH, K.L.; WATSON, C.J.; MÜLLER, C.; LAUGHLIN, R.J.; CHADWICK, D.R. Evidence that the efficacy of the nitrification inhibitor dicyandiamide (DCD) is affected by soil properties in UK soils. Soil Biology and Biochemistry, v.94, p.222-232, 2016. DOI: https://doi.org/10.1016/j.soilbio.2015.11.017.

NENDEL, C.; REUTER, S.; KUBIAK, R.; NIEDER, R. Nitrogen mineralization from mature bio-waste compost in vineyard soils. I. Long-term laboratory incubation experiments. Journal of Plant Nutrition and Soil Science, v.167, p.397-407, 2004. DOI: https://doi.org/10.1002/jpln.200320362.

NGUYEN, T.T.N.; XU, C.-Y.; TAHMASBIAN, I.; CHE, R.; XU, Z.; ZHOU, X.; WALLACE, H.M.; BAI, S.H. Effects of biochar on soil available inorganic nitrogen: a review and meta-analysis.
Geoderma, v.288, p.79-96, 2017. DOI: https://doi.org/10.1016/j. geoderma.2016.11.004.

OLIVEIRA, P.A.V. de; HIGARASHI, M.M. Unidade de compostagem para o tratamento dos dejetos de suínos. Concórdia: Embrapa Suínos e Aves: 2006. (Embrapa Suínos e Aves. Documentos, 114). Available at: $<$ www.embrapa.br/suinose-aves/busca-de-publicacoes/-/publicacao/856117/unidadede-compostagem-para-o-tratamento-dos-dejetos-de-suinos $>$. Accessed on: June 32018.

PAUL, E.A. (Ed.). Soil microbiology, ecology, and biochemistry. $4^{\text {th }}$ ed. San Diego: Academic Press, 2015. 582p. DOI: https://doi.org/10.1016/C2011-0-05497-2.

PEZZOLLA, D.; SAID-PULLICINO, D.; RAGGI, L.; ALBERTINI, E.; GIGLIOTTI, G. Short-term variations in labile organic $\mathrm{C}$ and microbial biomass activity and structure after organic amendment of arable soils. Soil Science, v.178, p.474-485, 2013. DOI: https://doi.org/10.1097/SS.0000000000000012.

PIMENTEL, P.M.; SILVA JR., C.N.; MELO, D.M.A.; MELO, M.A.F.; MALDONADO, G.; HENRIQUE, D.M. Caracterização e uso de xisto para adsorção de chumbo (II) em solução. Cerâmica, v.52, p.194-199, 2006. DOI: https://doi.org/10.1590/ S0366-69132006000300013.

RIBAS, L. Influência do processo de pirólise sobre as camadas de folhelho pirobetuminoso de São Mateus do Sul - PR. 2012. 154p. Dissertação (Mestrado) - Universidade Federal do Paraná, Curitiba.

SAID-PULLICINO, D.; KAISER, K.; GUGGENBERGER, G.; GIGLIOTTI, G. Changes in the chemical composition of waterextractable organic matter during composting: distribution between stable and labile organic matter pools. Chemosphere, v.66, p.2166-2176, 2007. DOI: https://doi.org/10.1016/j. chemosphere.2006.09.010.

SANTOS, H.G. dos; JACOMINE, P.K.T.; ANJOS, L.H.C. dos; OLIVEIRA, V.A. de; LUMBRERAS, J.F.; COELHO, M.R.; ALMEIDA, J.A. de; CUNHA, T.J.F.; OLIVEIRA, J.B. de. Sistema brasileiro de classificação de solos. 3.ed. rev. e ampl. Brasília: Embrapa, 2013. 353p.

SOIL SURVEY STAFF. Keys to soil taxonomy. $12^{\text {th }}$ ed. Washington: USDA, 2014. 360p.

STOTZKY, G. Microbial respiration. In: BLACK, C.A. (Ed.). Methods of soil analysis: part 2: chemical and microbiological properties. Madison: American Society of Agronomy, 1965. p.1550-1572. (Agronomy, 9). DOI: https://doi.org/10.2134/ agronmonogr9.2.c62.

TEDESCO, M.J.; GIANELLO, C.; BISSANI, C.A.; BOHNEM, H.; VOLKWEISS, S.J. Análises de solo, plantas e outros materiais. 2.ed. rev. e ampl. Porto Alegre: UFRGS, 1995. 174p. (UFRGS. Boletim técnico; 5).

WEBB, J.; PAIN, B.; BITTMAN, S.; MORGAN, J. The impacts of manure application methods on emissions of ammonia, nitrous oxide and on crop response - a review. Agriculture, Ecosystems and Environment, v.137, p.39-46, 2010. DOI: https://doi.org/10.1016/j.agee.2010.01.001. 


\section{ERRATA: Mineralization of pig slurry compost treated with retorted oil shale and dicyandiamide in two contrasting soils}

In the paper "Mineralization of pig slurry compost treated with retorted oil shale and dicyandiamide in two contrasting soils", DOI: 10.1590/S1678-3921.pab2021.v56.01393, published in Pesquisa Agropecuária Brasileira, v.56, e01393, 2021, on page 1, left column, line 4, where it reads:

"Stefen Barbosa Pujo",

it should read:

"Stefen Barbosa Pujol". 